\title{
PENERAPAN PEMBELAJARAN KOOPERATIF TIPE NUMBERED HEADS TOGETHER (NHT) UNTUK MENINGKATKAN SELF-EFFICACY SISWA
}

\author{
Fitriana Yolanda ${ }^{1}$ \\ Prodi Pendidikan Matematika Universitas Islam Riau. Jalan Kaharuddin Nasution No 113 Marpoyan, Riau ${ }^{1}$ \\ e-mail: fitrianayolanda@edu.uir.ac.id
}

\begin{abstract}
ABSTRAK
Penelitian ini bertujuan untuk meningkatkan self-efficacy siswa kelas VIII MTs YKWI Pekanbaru melalui Penerapan Pembelajaran Kooperatif Tipe Numbered Heads Together (NHT). Penelitian ini merupakan penelitian tindakan kelas. Teknik pengumpulan data pada penelitian ini adalah dengan menggunakan lembar pengamatan aktivitas guru dan siswa serta angket self-efficacy. Berdasarkan data yang diperoleh menunjukkan bahwa terjadi peningkatan self-efficacy siswa dari skor dasar ke Ulangan Harian I, dari Ulangan Harian I ke Ulangan Harian II. Adapun persentase self-efficacy siswa pada Ulangan Harian I sebesar 54,6 \% dengan kategori cukup mandiri dan pada Ulangan Harian II menaik sebesar 77,2\% dengan kategori setingkat lebih tinggi dari kategori ulangan harian I yaitu mandiri. Dari hasil penelitian dan pembahasan, maka dapat disimpulkan bahwa penerapan pembelajaran kooperatif tipe Numbered Heads Together (NHT) dapat meningkatkan self-efficacy siswa kelas VIII MTs YKWI Pekanbaru.
\end{abstract}

Kata kunci :

Numbered Heads Together; self-efficacy siswa.

\begin{abstract}
This study aims to improve the self-efficacy of YKWI Pekanbaru MTs students in class VIII through the Application of Numbered Heads Together (NHT) Cooperative Learning. This research is a classroom action research. The data collection technique in this study is to use the observation sheet of teacher and student activities as well as the self-efficacy questionnaire. Based on the data obtained shows that there is an increase in students' self-efficacy from the basic score to Deuteronomy I Daily, from Deuteronomy I Daily to Deuteronomy II. The percentage of students' self-efficacy in Daily Deuteronomy was $54.6 \%$ with a fairly independent category and in Daily Deuteronomy II it increased by $77.2 \%$ with a higher level category than the daily test I category which was independent. From the results of research and discussion, it can be concluded that the application of Numbered Heads Together (NHT) type of cooperative learning can improve the self-efficacy of class VIII YKWI MTs in Pekanbaru.
\end{abstract}

Keywords :

Numbered Heads Together; student self-efficacy

\section{PENDAHULUAN}

Salah satu masalah yang dihadapi dalam dunia pendidikan saat ini adalah masalah proses pembelajaran. Dalam proses pembelajaran, siswa kurang didorong untuk mengembangkan kemampuan intelektual yang melibatkan kemampuan berpikir sistematis, bernalar, kreatif, kritis dan kemampuan berkomunikasi. Berbagai kemampuan ini terakumulasi dalam ranah kognisi setiap manusia yang digunakan untuk memecahkan berbagai masalah. Khusus bagi siswa, keterampilan ini sangat menentukan tingkat keberhasilan menyerap, memahami, menggunakan, menganalisis, membuat sintesa dan mengevaluasi konsep dari suatu ilmu pengetahuan.

Berdasarkan hasil wawancara yang peneliti lakukan di MTs YKWI Pekanbaru pada tanggal 4 April 2016, menyatakan bahwa dalam proses pembelajaran masih ada siswa yang bermalas-malasan dan kurang aktif. Kemudian masih ada siswa yang menyontek saat mengerjakan latihan bahkan ada siswa yang bercerita saat mengerjakan latihan. Selain itu self-eficacy siswa juga masih rendah, hal ini terjadi karena siswa menganggap bahwa matematika pelajaran yang sulit dan terlalu banyak rumus. Pembelajaran masih berpusat 


\section{$\pi$ (Phi)}

pada guru, dan guru belum pernah menggunakan model pembelajaran apapun kecuali metode konvensional yaitu ceramah, sehingga siswa menjadi bosan dengan pembelajaran yang sama pada setiap pertemuan.

Menurut Bandura (Astutik, 2012) mendefinisikan "efikasi diri sebagai kepercayaan pada kemampuan diri dalam mengatur dan melaksanakan suatu tindakan". Self-efficacy menentukan keyakinan bagaimana seseorang merasa, berpikir, memotivasi dirinya dalam berkelakuan. Keyakinan menghasilkan perbedaan yang berdampak melalui empat aspek yakni kognitif, motivasi, afektif dan aspek lain. Remaja yang memiliki selfefficacy yang positif adalah remaja yang yakin jikalau remaja tersebut sanggup melaksanakan tugas perkembangan sebagai seorang remaja dan lebih cenderung bisa melalui masa-masa remaja ini dengan baik. Sebaliknya remaja yang memiliki selfefficacy yang negatif yaitu remaja yang cenderung mengalami kebingungan dan bermasalah pada masa-masa remaja ini. Banyak faktor yang berpengaruh terhadap pembentukan self-efficacy pada remaja. Siswa yang memiliki kepercayaan diri akan kemampuannya, maka siswa tersebut akan memotivasi dirinya sendiri ketika menyelesaikan masalah-masalah yang terdapat di dalam pembelajaran matematika.

Salah satu pembelajaran yang dapat meningkatkan self-efficacy siswa adalah pembelajaran kooperatif. Menurut Sanjaya (2006) menyatakan bahwa pembelajaran kooperatif merupakan model pembelajaran dengan menggunakan sistem pengelompokkan / tim kecil, yaitu antara empat sampai enam orang yang mempunyai latar belakang kemampuan akademik, jenis kelamin, ras atau suku yang berbeda (heterogen). Lebih lanjut Slavin (2005:287), menyatakan cooperative learning merupakan proses penciptaan lingkungan pembelajaran kelas yang memungkinkan siswa dapat bekerja bersama-sama dalam kelompok kecil yang heterogen dalam mengerjakan tugas. Menurut Suyatno (2009) "Pembelajaran kooperatif adalah kegiatan pembelajaran dengan cara berkelompok untuk bekerja sama saling membantu mengkontruksi konsep, menyelesaikan persoalan atau inkuiri”.

Berdasarkan pengertian-pengertian pembelajaran kooperatif di atas dapat disimpulkan bahwa pembelajaran kooperatif adalah suatu proses pembelajaran di dalam kelas, dimana siswanya belajar secara bersama-sama dalam kelompok yang heterogen dalam mengerjakan tugas sehingga siswa mampu memaksimalkan kemampuan yang mereka. Selanjutnya salah satu tipe pembelajaran kooperatif yang dapat meningkatkan self-efficacy siswa adalah tipe Numbered Heads Together (NHT). Numbered Heads Together (NHT) dikembangkan oleh Spencer Kagen 1993 dalam (Ibrahim, 2000) untuk melibatkan lebih banyak siswa dalam menelaah materi yang tercakup dalam suatu pelajaran dan mengecek pemahaman mereka terhadap isi pelajaran tersebut.

Berdasarkan uraian di atas, peneliti tertarik untuk melakukan penelitian yang berjudul "Penerapan Pembelajaran Kooperatif Tipe Numbered Heads Together (NHT) Untuk Meningkatkan Self-Efficacy Siswa". Adapun tujuan dilakukan penelitian ini yaitu untuk memperbaiki proses pembelajaran dan meningkatkan selfefficacy siswa kelas VIII Mts YKWI Pekanbaru melalui penerapan pembelajaran kooperatif tipe Numbered Head Together (NHT).

\section{METODE PENELITIAN}

Penelitian ini adalah Penelitian Tindakan Kelas (PTK) yang dilaksanakan di kelas VIII MTS YKWI Pekanbaru Tahun ajaran 2016/2017. Subjek penelitian ini adalah siswa kelas VIII MTS YKWI Pekanbaru yang berjumlah 20 orang siswa. Data tentang aktivitas guru dan siswa selama proses pembelajaran dikumpulkan dengan 


\section{$\pi$ (Phi)}

menggunakan lembar pengamatan, sedangkan data self-efficacy siswa dikumpulkan dengan menggunakan angket yang diberikan di akhir setiap siklus.

\section{1) Analisis Hasil Pengamatan}

Hasil pengamatan ini digunakan untuk memperoleh data tentang aktivitas siswa dan guru selama proses pembelajaran. Di sini pengamat mengamati aktivitas siswa dan guru sesuai dengan tuntutan Rencana Pelaksanaan Pembelajaran yang tersedia dalam lembar pengamatan.

\section{2) Analisis Self-Efficacy Siswa}

Hasil pengisian angket yang dilakukan oleh siswa pada setiap ulangan harian dapat menggambarkan peningkatan self-efficacy. Adapun perhitungan persentase self-efficacy dan kualifakasi persentase self-efficacy siswa (Fitriana, 2015:95)

Persentase skor jawaban

$$
=\frac{\text { Skor jawaban }}{\text { skor maksimal }} \times 100 \%
$$

Tabel 1. Kualifikasi persentase self-efficacy siswa

\begin{tabular}{ccc}
\hline No & Persentase & Kriteria \\
\hline 1 & $P \geq 80 \%$ & Sangat Mandiri \\
2 & $60 \% \leq P \leq 80 \%$ & Mandiri \\
3 & $40 \% \leq P \leq 60 \%$ & Cukup Mandiri \\
4 & $20 \% \leq P \leq 40 \%$ & Tidak Mandiri \\
5 & $P \leq 20 \%$ & Sangat Tidak \\
& & Mandiri \\
\hline
\end{tabular}

\section{HASIL DAN PEMBAHASAN}

Analisis Peningkatan Self-Efficacy Siswa

Hasil skor ulangan harian I ke ulangan harian II siswa kelas VIII Mts YKWI Pekanbaru dapat menggambarkan peningkatan self-efficacy siswa pada siklus I dan siklus II.Untuk lebih jelasnya dapat dilihat pada tabel di bawah ini:

Tabel 2. Self-Efficacy Siswa Pada Ulangan Harian I dan Ulangan Harian II

\begin{tabular}{ccc}
\hline & UH I & UH II \\
\hline Jumlah Skor & 1092 & 1544 \\
Persentase (\%) & $54,6 \%$ & $77,2 \%$ \\
Kategori & Cukup Mandiri & Mandiri \\
\hline
\end{tabular}

Berdasarkan tabel 2 di samping, analisis self-efficacy siswa dari skor dasar ke ulangan harian I, dari ulangan harian I ke ulangan harian II terjadi peningkatan pada setiap siswa baik pada jumlah skornya maupun pada persentasenya. Pada siklus I yaitu pada ulangan harian I terlihat bahwa Self-Efficacy siswa sebesar $54,6 \%$ artinya termasuk kedalam kategori cukup mandiri. Sedangkan pada siklus 2 yaitu pada ulangan harian II terlihat bahwa Self-Efficacy siswa sebesar 77,2\% artinya termasuk kedalam kategori mandiri. Berdasarkan analisis di atas dapat disimpulkan bahwa self-efficacy siswa dapat ditingkatkan melalui pembelajaran kooperatif tipe Numbered Head Together (NHT).

\section{Pembahasan Hasil Penelitian}

Penelitian ini dilaksanakan di kelas VIII MTS YKWI Pekanbaru dari tanggal 4 Oktober 2016 sampai tanggal 27 Oktober 2016. Berdasarkan pengamatan selama proses pembelajaran, terlihat bahwa terjadi peningkatan proses pembelajaran di setiap pertemuan. Dari lembar pengamatan aktivitas guru dan siswa terlihat bahwa siswa semakin percaya diri dan memiliki keyakinan diri dalam mengikuti pembelajaran. Guru selalu memberikan kesempatan kepada setiap kelompok untuk berdiskusi dalam menemukan konsep pelajaran. Guru juga memberikan bimbingan dalam memberi penyelesaian dari masalah yang dialami siswa.

Dari analisis self-efficacy, pelaksanaan pembelajaran kooperatif tipe Numbered Head Together (NHT) dapat meningkatkan self-efficacy siswa secara keseluruhan. Hal ini terlihat dari analisis self-efficacy siswa sebelum dilaksanakannya pembelajaran kooperatif tipe Numbered Head Together (NHT) dan setelah dilaksanakannya pembelajaran kooperatif tipe Numbered Head Together (NHT), dimana persentase self-efficacy siswa pada ulangan harian I sebesar 54,6\% meningkat pada ulangan harian II sebesar 77,2\%. Selanjutnya kategori self-efficacy siswa pada pada ulangan harian I termasuk kedalam kategori cukup mandiri sedangkan pada ulangan 


\section{$\pi$ (Phi)}

harian II termasuk kedalam kategori mandiri. Ini berarti self-efficacy siswa terjadi peningkatan setelah diterapkannya pembelajaran kooperatif tipe Numbered Head Together (NHT).

Dapatan ini didukung oleh penelitian yang dilakukan oleh Wahyuni dan Yolanda (2018) menyatakan bahwa self-efficacy siswa dapat meningkat dengan menerapkan pembelajaran kooperatif tipe Numbered Head Together (NHT). Selanjutnya Yolanda (2017) memperoleh hasil penelitian menyatakan bahwa hasil belajar juga dapat ditingkatkan dengan penerapan model pembelajaran kooperatif tipe Numbered Head Together.

Berdasarkan pembahasan yang telah di jelaskan di atas dapat disimpulkan bahwa penerapan pembelajaran kooperatif tipe Numbered Head Together (NHT) dapat memperbaiki proses pembelajaran dan meningkatkan self-efficacy siswa kelas VIII MTs YKWI Pekanbaru pada materi relasi dan fungsi.

\section{SIMPULAN DAN SARAN}

Berdasarkan hasil penelitian dan pembahasan yang telah dikemukakan di atas, maka dapat disimpulkan bahwa penerapan pembelajaran kooperatif tipe Numbered Heads Together (NHT) dapat meningkatkan self-efficacy siswa kelas VIII Mts YKWI Pekanbaru pada materi relasi dan fungsi.

\section{DAFTAR PUSTAKA}

Astutik, E. W., dkk. (2012). Studi Tentang Regulasi Diri Dalam Belajar, Efikasi Diri dan Prestasi Belajar Matematika. Prediksi, Kajian Ilmiah Psikologi. Vol. 01, No. 2 Juli-Desember 2012, Hal: 203-206.

Fitriana, S., dkk. (2015). Pengaruh Efikasi Diri, Aktivitas, Kemandirian Belajar dan Kemampuan Berpikir Logis Terhadap Hasil Belajar Matematika Pada Siswa Kelas VIII SMP. Journal
Of EST. Vol. 01, No. 2 September 2015. Hal: 86-101.

Ibrahim, M, dkk. 2000. Pembelajaran Kooperatif. Surabaya: University Press.

Sanjaya, W. (2006). Strategi Pembelajaran. Bandung: Kencana Prenada Media Group.

Slavin, R. (2005). Cooperative Learning; Teori, Riset dan Praktik. Bandung: Nusa Media

Suyatno. (2009). Menjelajah Pembelajaran Inovatif. Sidoarjo: Masmedia Buana Pustaka.

Wahyuni, P dan Yolanda, F. 2018. Penerapan Pembelajaran Kooperatif Tipe Numbered Heads Together (NHT) Untuk Meningkatkan Kemampuan Komunikasi Matematis dan Self-Efficacy Siswa Kelas VIII Mts YKWI Pekanbaru. Jurnal AdMathEdu. Vol 2 No. 2. Hal: 159170.

Yolanda, F. (2017). Penerapan Model Pembelajaran Kooperatif Tipe Numbered Heads Together untuk Meningkatkan Hasil Belajar Matematika Siswa Kelas VIII2 SMP Muhammadiyah 2 Pekanbaru. Jurnal Aksiomatik, Vol 5 No 2, Hal: 145-150. 